\title{
Foreign trade and innovation: evidence from Ukraine
}

\author{
Daniel Butyter \\ University of Wroctaw \\ Poland \\ daniel.butyter@prawo.uni.wroc.pl
}

\author{
Małgorzata Wachowska \\ University of Wroctaw \\ Poland \\ mawachow@prawo.uni.wroc.pl
}

Abstract. The creation and spread of new ideas are considered to be crucial for innovation, and consequently for growth of countries and regions. One of the mechanisms through which knowledge is transferred internationally is foreign trade. In the light of the above, the aim of this paper is to show the relationship between foreign trade and innovation of Ukraine as measured with the number of patent applications in 2004-2013. A correlation method has been used in the paper. Pearson correlation coefficients have been calculated, separately for the relationships between the values of imports and exports of goods and the number of inventions submitted for patent protection by Ukrainian entities. The analysis of Ukrainian data has not confirmed the commonly formulated hypothesis that foreign trade is a carrier for innovativeness. Foreign trade of Ukraine generally has no effect on the improvement of innovation of this country. It is only exports to countries being technological leaders (United States, Japan, Germany) that contribute to improvement in inventiveness of Ukrainian entities, but also in this case the role of foreign trade in increasing innovation in Ukraine can hardly be recognized as significant.

Keywords: economy innovativeness, foreign trade, patent applications, Ukraine.

JEL Classification: F14, F20, O30

\section{INTRODUCTION}

Since endogenous growth theory was formulated (Romer 1986; Lucas 1988), in which knowledge was recognized as crucial for long-term rate of GDP growth, and consequently for the well-being of countries, more and more attention has been paid to the possibilities of creating new knowledge and acquiring foreign know-how, but it is rather technologically advanced countries like e.g. United States which are interested 
in creating breakthrough ideas than developing or less developed countries like e.g. Ukraine which mainly want to use foreign scientific achievements. The ambition of less developed economies is rather to catch up with the world's technological leaders and hence they are to a larger degree inclined to generate incremental innovations of imitative nature and acquire foreign solutions, especially from the countries which are most abundant in knowledge and from the so-called centers of excellence.

There are many mechanisms through which knowledge can be transferred internationally. The most recent ones include foreign direct investment (Branstetter 2000; Konings 2001; Kolasa 2008; Gorodnichenko et al. 2014; Zhang et al. 2014) and international strategic alliances (Branstetter, Sakakibara 1998, 2002; Kaiser, Kuhn 2012) and the traditional ones include e.g. foreign trade.

International trade can contribute to knowledge transfers between countries in two ways. On the one hand, knowledge and technology embodied in imported goods make it possible to take advantage of R\&D activities undertaken by other countries, and on the other hand, export activity may be a carrier for new ideas. The stock of knowledge of exporters, and thanks to spillovers also in the whole national economy, may increase as a result of their contacts with foreign customers. Buyers from abroad, expecting products of high quality or low prices, tend to offer even free technical assistance to manufacturers, frequently give them know-how coming from other suppliers or directly supervise the production process. Not only contacts with trade partners but also with technologically more advanced foreign competitors may contribute to improvement of innovation of exporters who, if willing to compete in the global market, are in a way forced to keep improving quality of their products and production processes.

The purpose of this paper is to show the relationship between foreign trade and innovation of Ukraine in 2004-2013 as measured by the number of patent applications.

The determination of the role of foreign trade in international diffusion of innovation seems particularly important in the case of Ukraine, which signed the association agreement with the EU in 2014 that is to create a deep and comprehensive free trade area. Consequently, a significant increase in Ukraine's trade is expected to occur.

Traditionally, the innovation of a country is assessed on the basis of the number of obtained patents (in both absolute as well as per capita terms). It stems from the fact that patent protection is granted to breakthrough innovations with special meaning. Using the number of patents as a measure of innovation seems therefore justified. However, as it is increasingly indicated, although the number of patents of a country gives information about the creative potential of its inhabitants, it relates to the past. Current innovation is better reflected by the number of inventions filed for patent protection. It is due to the fact that the waiting time for the patent protection is very long (as long as 10 to 15 years) in many countries, which means that a patent granted today actually reports inventive activity 10 to 15 years ago. Hence, a better measure of current innovation is not the number of patents but the number of patent applications.

A correlation method has been used for determining the relationship between foreign trade and innovation of Ukraine. Pearson correlation coefficients have been calculated, separately for the relationships between the values of imports/exports of goods and the number of inventions. The paper takes into account only trade in goods and ignores trade in services because in the case of services the created innovations cannot be subject to patent protection on formal grounds. A patent can be granted only to innovations of technical nature, i.e. inventions.

Preliminary research has shown that in the majority of cases an increase in the volume of exports/ imports of Ukraine is accompanied by a decrease in inventions filed by Ukrainian entities for patent protection and a decrease in exports/imports is accompanied by an increase in patent applications. It suggests the existence of negative correlation. The main purposes of the calculation of Pearson correlation coefficients 
is therefore to confirm the preliminary research and determine the strength of the relationship. Hence, the correlation method seems sufficient in this case.

For the purpose of this paper, data from the State Service for Intellectual Property of Ukraine pertaining to patent applications of Ukrainian entities as well as data from the State Statistics Service of Ukraine pertaining to foreign trade have been used.

\section{THE RELATIONSHIP BETWEEN FOREIGN TRADE AND INNOVATION OF A COUNTRY. LITERATURE REVIEW}

Although in the literature of the field different opinions can be found on the role of trade in international diffusion of innovation, yet a strong majority of researchers formulates the hypothesis that both exports and imports are important channels of knowledge flows. This lack of common position is a result of many factors, e.g. specifics of a country under study or research method used, however, probably the most important one is adoption of different indicators of innovation.

In many analyses, the relationship between trade (or exports and imports separately) and productivity of domestic factors of production (most often total factor productivity) is examined. If positive correlation is found, it is assumed that foreign trade has positive effect on innovativeness since productivity growth - as it is presumed - must be a result of increased stock of knowledge and introduction of innovative solutions. Hence it is eventually assumed that if an increase in trade is accompanied by an increase in productivity then trade is an important carrier of innovation.

Studies can also be found in which the number of obtained patents or the number of patent applications are measures of innovation. On the one hand, these measures are better approximation of the innovation level, and on the other hand they only partially reflect possible improvement of innovation. It stems from the fact that many innovations (e.g. in many countries these are software or innovations of organizational nature) cannot be or, because of other reasons (the decision to keep them trade secret), are not submitted for patent protection.

One of the first important contributions to discussion on the role of international trade in acquisition of foreign know-how is the analysis by Globerman, Kokko and Sjöholm (1996) in the light of which innovation of Sweden increased in 1973-1986 owing to its trade contacts. The hypothesis of an important role of trade in increasing innovation of the economy was confirmed also by the research by Bitzera and Geishecker (2006), but mainly under inter-industry trade conditions. Under intra-industry trade conditions, the positive effects of spillovers through trade are weakened by negative effects of increased competition. Consistent with the above results are also conclusions by De Loecker (2007) which show a strong relationship between the opening of Belgian textile industry to trade and its productivity. Meanwhile, an increase in skills of skilled workforce resulting from increased trade was observed by Dutt and Traca (2010), especially under conditions of trade with countries with ineffective intellectual property protection. Similarly, research by Van Long et al. (2011) shows that trade liberalization - by increasing trade - influences incentives of enterprises to innovate, consequently increasing aggregated $R \& D$ and productivity of industry. Finally, in the light of the more recent analyses, liberalization of trade has led to improvement in the level of innovation in China, with the final increase in productivity being a result of the productivity-enhancing effect of tariff reduction for intermediates and productivity-reducing effect of tariff reduction for finished products $(\mathrm{Hu}$, Liu, 2014).

The positive effects of foreign trade in the form of improved innovation has been found also for the Ukrainian economy by Gorodnichenko et al. (2010), who showed that the openness to foreign trade pro- 
motes factor productivity improvement as well as by Moskalyk (2009), who observed that it is particularly imports from highly innovative countries and imports of high-tech products which are connected with the increase in the productivity of Ukrainian entities.

One of the first works to examine the relationship between imports and innovativeness and not the one between international trade in general and innovation, was the analysis by Coe and Helpmann (1995) who on the basis of data from 21 OECD countries proved that productivity of a country depends on the stock of R\&D capital of its trade partners, with smaller countries benefiting from spillovers to a greater extent. Using modified methodology of Coe and Helpman (1995), Lichtenberg and van Pottelsberge de la Potterie (1996) not only confirmed the conclusions of their predecessors but they even proved that imports are of larger meaning for productivity growth with the use of their modified methodology. The hypothesis of innovations embodied in imported goods was confirmed also by Sjöholm (1999) with the use of data from Indonesian industry, Lin and Lin (2010) with the use of data from Taiwan and Blomm et al. (2011) on the basis of Chinese data.

One of the first studies attempting to examine the relationship between export and innovation is the work by Aw and Hwang (1995) in which positive correlation between exports and productivity growth in Taiwanese industry was found. Unfortunately, Aw and Hwang (1995) - similarly to Sjöholm (1999) who found an analogous relationship for Indonesia - failed to test causation between exports and improvement of innovation. Therefore, the results of their research do not provide explicit proof of the hypothesis of learning through exporting. The explicit evidence that exports promote innovative behavior by enterprises were found in studies by Jung (2004) based on data from Korea, Lin and Lin (2010) using Taiwanese data and Lee (2011) in which a positive albeit weak relationship between exports and productivity in Malaysia was found.

However, some researchers, as it has already been mentioned, do not confirm that engagement of enterprises in import or export activity contributed to improving their innovation. Some went so far as to show the existence of negative relationship, suggesting that international trade „is harmful” to innovation of a country. The hypothesis about innovation embodied in imports was rejected by Keller (1998). Meanwhile, Clerides et al. (1998) found that the positive relationship between exports and productivity results solely from the fact that it is more effective entities who engage in export. Finally, Bernard and Bradford (1999) showed that export activity is related to lower levels of innovation.

It is increasingly emphasized, however, that there is feedback between foreign trade, especially export activity, and innovation. It means on the one hand that international trade can contribute to improving innovation of countries participating in it, and on the other hand it is innovations implemented in the production process allowing to increase its productivity and quality that may be responsible for increased trade. The above opinion is held, among the others, by Blind and Jungmittag (2005) who showed that export performance of Germany is explained mainly by their innovative potential, by Marquez-Ramos and Martinez-Zarzoso (2010) who proved existence of a similar relationship for Spain and Rubini (2014) who went so far as to emphasize that changes in trade volumes are not possible without innovation.

\section{INTERNATIONAL TRADE AND INNOVATION OF UKRAINE. RESULTS OF THE ANALYSIS}

In the period under study, covering the years 2004-2013, both exports and imports of Ukraine showed an increasing tendency, although a considerable drop in value of both figures could be observed in 2009 (Figure 1). Also in 2013 foreign trade values were smaller than in the preceding year, but in this case the data no longer include Crimea and Sevastopol. 
Table 1

Export and import values of Ukraine in the years 2004-2013

\begin{tabular}{|c|c|c|}
\hline Year & Exports (\$ million) & Imports (\$ million) \\
\hline 2004 & 32672.3 & 28996.0 \\
\hline 2005 & 34286.7 & 36141.1 \\
\hline 2006 & 38367.7 & 45034.5 \\
\hline 2007 & 49248.1 & 60669.9 \\
\hline 2008 & 66954.4 & 85535.4 \\
\hline 2009 & 39702.9 & 45435.6 \\
\hline 2010 & 51430.5 & 60740.0 \\
\hline 2011 & 68394.2 & 82608.2 \\
\hline 2012 & 68809.8 & 84658.1 \\
\hline $2013^{*}$ & 62305.9 & 75834.6 \\
\hline
\end{tabular}

*excl. Crimea and Sevastopol

Source: State Statistics Service of Ukraine.

In the same period (2004-2013), the number of patent applications showed a decreasing tendency, which was particularly evident in the years 2004-2009 (Table 2). Although the number of Ukrainian inventions filed for patent protection had begun to grow since 2010, as soon as in 2012 the inventive activity of Ukrainian entities decreased.

Table 2

The number of Ukrainian patent applications in the years 2004-2013

\begin{tabular}{|c|c|}
\hline Year & Number of patent applications \\
\hline 2004 & 4090 \\
\hline 2005 & 3538 \\
\hline 2006 & 3474 \\
\hline 2007 & 3440 \\
\hline 2008 & 2825 \\
\hline 2009 & 2429 \\
\hline 2010 & 2553 \\
\hline 2011 & 2641 \\
\hline 2012 & 2483 \\
\hline 2013 & 2860 \\
\hline
\end{tabular}

Source: State Service for Intellectual Property of Ukraine.

The preliminary analysis of patent applications filed by Ukrainian entities - being a measure of Ukraine's innovation - and the values of imports and exports of goods of this country as well as the calculation of the correlation coefficients has allowed for the formulation of several basic conclusions. 


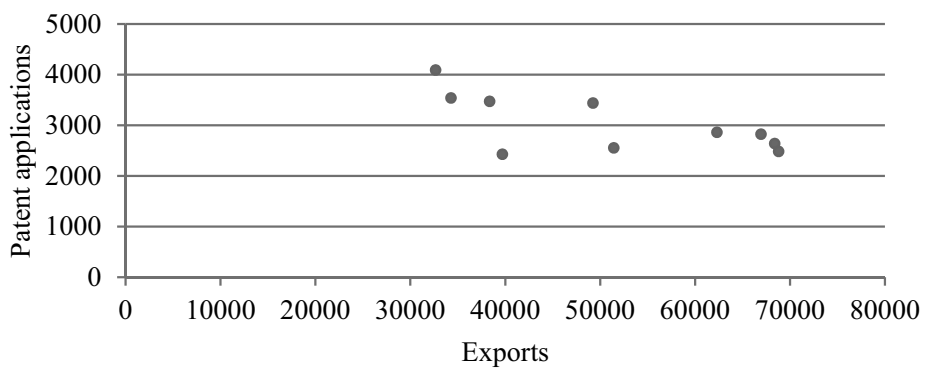

Fig. 1. Correlation chart of scatter between exports in general and the number of patent applications of Ukraine Source: Own elaboration on the basis of data from the State Service for Intellectual Property of Ukraine and the State Statistics Service of Ukraine.

Firstly, the export activity of Ukraine in general does not contribute to improvement in its innovation. The correlation between exports and the total number of submitted inventions, both within domestic and international procedures, is negative (Fig. 1) - the Pearson correlation coefficient is -0.67 .

Secondly, imports of goods in Ukraine in general are not a channel of international diffusion of innovation and do not stimulate increased innovation in entities in this country. Similarly, as it was the case with export activity, also in this case the correlation between imports and the number of filed inventions is negative (Fig. 2). The Pearson correlation coefficient is -0.68 , respectively.

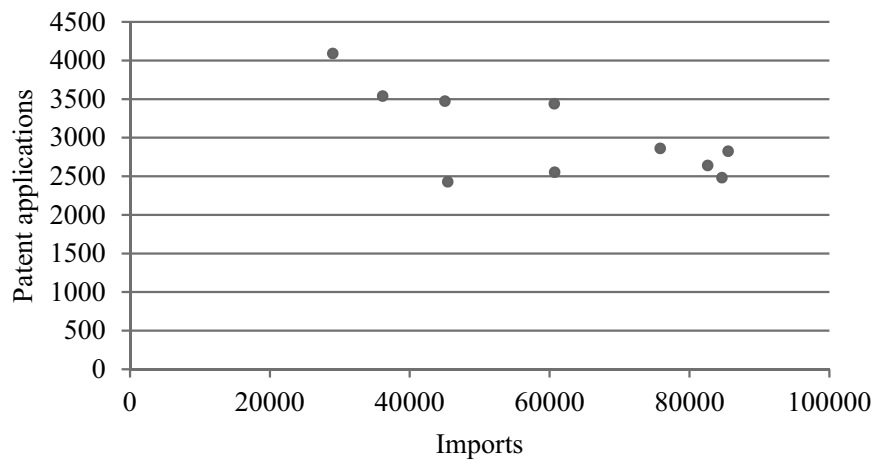

Fig. 2. Correlation chart of scatter between imports in general and the number of patent applications of Ukraine Source: Own elaboration on the basis of data from the State Service for Intellectual Property of Ukraine and the State Statistics Service of Ukraine. 


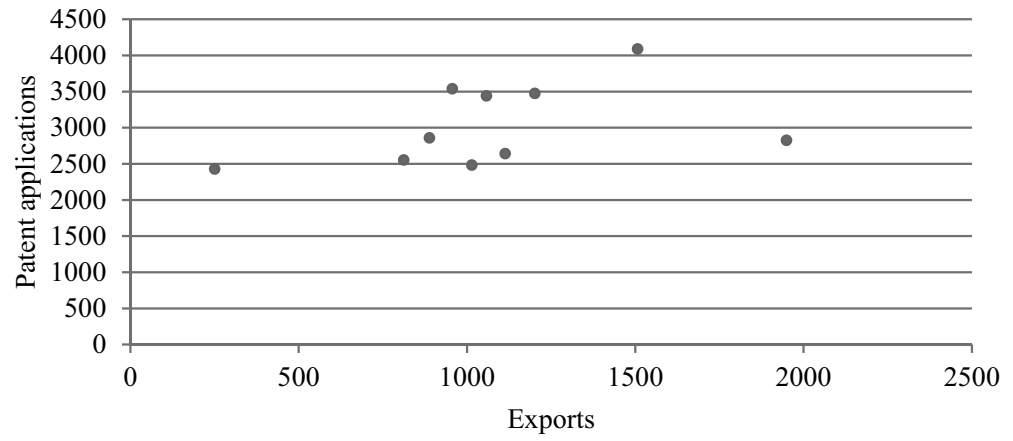

Fig. 3. Correlation chart of scatter between exports to the US and the number of patent applications of Ukraine. Source: Own elaboration on the basis of data from the State Service for Intellectual Property of Ukraine and the State Statistics Service of Ukraine.

The analysis of Ukrainian data for the relationship between foreign trade with technological leader countries only ${ }^{1}$ and innovation allowed for the formulation of another conclusion. Although imports of these countries do not provide any benefits in the form of improved level of innovation of Ukrainian entities, the effect of exports is not so explicit. The correlation between imports of goods from these countries and the number of patent applications is always negative while it is frequently positive between exports and the number of filed inventions, although usually little significant. The Pearson correlation coefficient between exports of Ukraine to the United States, Japan and Germany and the number of inventions submitted by Ukrainian entities is $0.42,-0.36,0.12$, respectively (Fig. 3, 4, 5). Meanwhile, the correlation coefficient between imports of Ukraine from the United States, Japan and Germany and innovation as measured by the number of patent applications is $-0.70,-0.24,-0.57$, respectively.

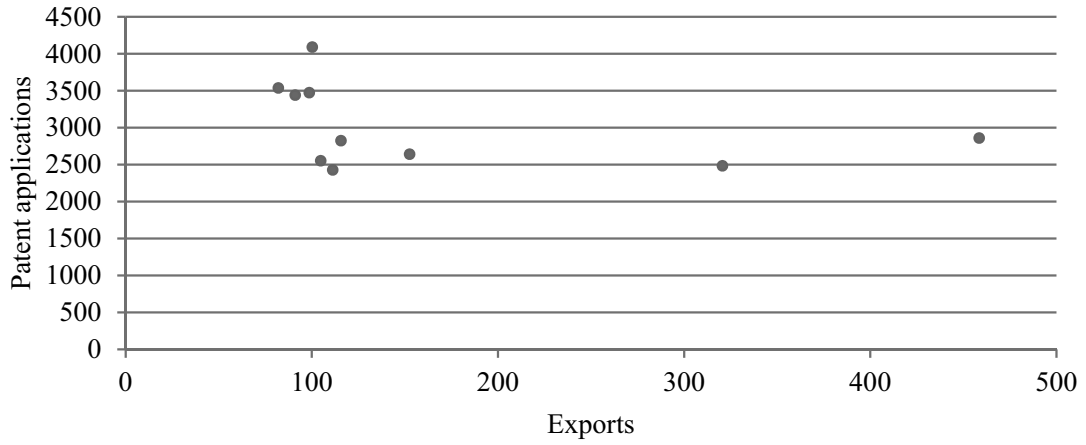

Fig. 4. Correlation chart of scatter between exports to Japan and the number of patent applications of Ukraine Source: Own elaboration on the basis of data from the State Service for Intellectual Property of Ukraine and the State Statistics Service of Ukraine.

1 According to the ranking of World Intellectual Property Organization technological leaders include the United States, Japan and Germany. 


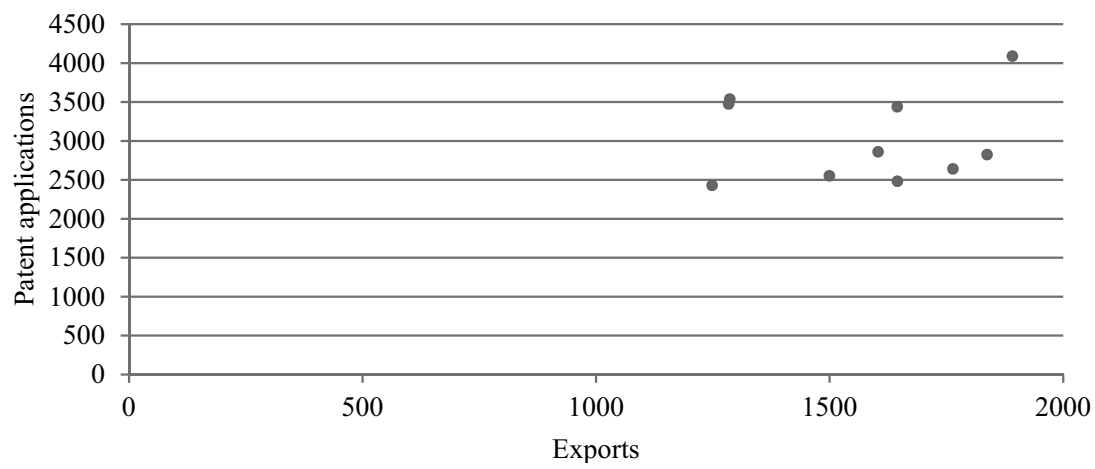

Fig. 5. Correlation chart of scatter between exports to Germany and the number of patent applications of Ukraine Source: Own elaboration on the basis of data from the State Service for Intellectual Property of Ukraine and the State Statistics Service of Ukraine.

For comparison, the foreign trade of Ukraine with countries on the lowest level of technological development (Montenegro, Niger, Papua New Guinea, Sudan, Tanzania, Togo, Zimbabwe) ${ }^{2}$, according to the number of obtained patents, is not related to the strongest negative correlation. The absolute values of the correlation coefficients are lower in comparison with those obtained for the relationship between the foreign trade of Ukraine in general and innovation of that country and are -0.25 (the relationship between exports and the number of patent applications) and -0.11 (the relationship between imports and the number of patent applications).

\section{CONCLUSIONS}

In the literature of the field, both in theoretical and empirical works, there is an opinion that foreign trade is an important channel of international diffusion of knowledge, contributing to the improvement of competitiveness of economies participating in it. The benefits in the form of increased level of invention are especially evident in countries being on the lower level of technological development which engage in trade with technologically advanced countries. Additionally, the larger the share of foreign trade with these countries in both total trade general and GDP, the larger these benefits.

However, the analysis of Ukrainian data has not confirmed the commonly formulated hypothesis. The Ukrainian foreign trade itself has no effect on the improvement of innovation of this country as measured by the number patent applications, which means that neither exports nor imports in general are carriers of knowledge. The situation is slightly different if foreign trade of Ukraine with technologically advanced countries only (United States, Japan, Germany) is taken into account, but also in this case the effect of foreign trade on invention of Ukrainian entities can hardly be recognized as significant.

With regard to trade in general, the correlation between both exports and imports and the number of inventions submitted by Ukrainian entities for patent protection is negative. In the case of trade with technologically leading countries, meanwhile, there is a positive correlation, especially between exports and the number of patent applications, although it is very week or moderate or even there is none.

2 Among the countries with which Ukraine had trade contacts in the period under study, the innovation - as measured by the number of obtained patents - was smallest in Montenegro, Niger, Papua New Guinea, Sudan, Tanzania, Togo, Zimbabwe. 


\section{REFERENCES}

Aw B., Hwang A. (1995), Productivity and export market: A firm-level analysis, Journal of Development Economics, Vol. 47, no. 2 pp. 313-332.

Bernard A., Bradford J.J. (1999), Exceptional exporter performance: cause, effect, or both?, Journal of International Economics, Vol. 47, no. 1, pp. 1-25.

Bitzer J., Geishecker I. (2006), What drives trade-related R\&D spillovers? Decomposing knowledge-diffusing trade flows, Economic Letters, Vol. 93, no. 1, pp. 52-57.

Blind K., Jungmittag A. (2005), Trade and the impact of innovations and standards: the case of Germany and the UK, Applied Economics, Vol. 37, no. 12, pp. 1385-1398.

Bloom N., Draca M., Van Reenen J. (2011), Trade induced technical change? The impact of Chinese imports on innovation, IT and productivity, NBER Working Paper Series, no. 16717.

Branstetter L. (2000), Is foreign direct investment a channel of knowledge spillovers? Evidence from Japan's FDI in the United States, NBER Working Paper Series, no. 8015.

Branstetter L., Sakakibara M. (1998), Japanese research consortia: a microeconometric analysis of industrial policy, Journal of Industrial Economics, Vol. 46, no. 2, pp. 207-233.

Branstetter L., Sakakibara M. (2002), When do research consortia work well and why? Evidence from Japanese panel data, American Economic Review, Vol. 92, no. 1, pp. 143-159.

Clerides S., Lach S., Tybout J. (1998), Is learning by exporting important? Micro-dynamic evidence from Colombia, Mexico, and Morocco, Quarterly Journal of Economics, Vol. 113, no. 3, pp. 903-948.

Coe D., Helpman E. (1995), International R\&D spillovers, European Economic Review, Vol. 39, no. 5, pp. 859-887.

De Loecker J. (2007), Product differentiation, multi-product firms and estimating the impact of trade liberalization on productivity, NBER Working Paper Series, no. 13155.

Dutt P., Traca D. (2010), With whom do you trade? Defensive innovation and the skill-bias, Canadian Journal of Economics, Vol. 43, no. 4, pp. 1198-1220.

Globerman S., Kokko A., Sjöholm F. (1996), Technology sourcing in Swedish MNEs and SMEs: Evidence from patent data, Working Paper Series in Economics and Finance, no. 125.

Gorodnichenko Y., Svejnar J., Terrell K. (2010), Globalization and innovation in emerging markets, American Economic Journal - Macroeconomics, Vol. 2, no. 2, pp. 194-226.

Gorodnichenko Y., Svejnar J., Terrell K. (2014), When does FDI have positive spillovers? Evidence from 17 transition market economies, Journal of Comparative Economics, Vol. 42, no 4, pp. 954-969.

Hu A.G., Liu Z. (2014), Trade liberalization and firm productivity: Evidence from Chinese manufacturing industries, Review of International Economics, Vol. 22, no. 3, pp. 488-512.

Jung M. (2004), A study on foreign knowledge spillovers through trade and the growth of labor productivity in the manufacturing sector of Korea, Korea Trade Review, Vol. 29, no. 2, pp. 5-30.

Kaiser U., Kuhn J.M. (2012), Long run effects of public-private research joint-ventures: The case of the Danish Innovation Consortia support scheme, "Research Policy", Vol. 41, no. 5, pp. 913-927.

Keller W. (1998), Are international R\&D spillovers trade-related? Analyzing spillovers among randomly matched trade partners, European Economic Review, Vol. 42, no. 8, pp. 1469-1481.

Kolasa M. (2008), How does FDI inflow affect productivity of domestic firms? The role of horizontal and vertical spillovers, absorptive capacity and competition, Journal of International Trade \& Economic Development, Vol. 17, no. 1, pp. $155-173$.

Konings J. (2001), The effects of foreign direct investment on domestic firms: Evidence from firm-level panel data in emerging economies, Economics of Transition, Vol. 9, no. 3, pp. 619-633.

Lee C. (2011), Trade, productivity, and innovation: Firm-level evidence from Malaysian manufacturing, Journal of Asian Economics, Vol. 22, no. 4, pp. 284-294. 
Lichtenberg F., van Pottelsberge de la Potterie B. (1996), International R\&D spillovers: a re-examination, NBER Working Paper Series, no. 5668.

Lin H-L., Lin E.S. (2010), Trade, and product innovation: Theory and evidence, Southern Economic Journal, Vol. 77, no. 2, pp. 434-464.

Lucas R. (1988), On the mechanics of economic development, Journal of Monetary Economics, no. 22, pp. 3-42.

Marquez-Ramos L., Martinez-Zarzoso I. (2010), The effect of technological innovation on international trade, Economics-the Open Access Open-Assessment e-Journal, Vol. 4, no. 201011.

Moskalyk R. (2002), Wplyw widkrytosti technologiczno intensywnoji torgiwli Ukrainy na formuwannja zony wilnoji torgiwli z JeS, Strategiczni Priorytety, Vol. 12, no. 3, pp. 143-150.

Romer P. (1986), Increasing returns and long-run growth, Journal of Political Economy, no. 94, pp. 1002-1037.

Rubini L. (2014), Innovation and the trade elasticity, Journal of Monetary Economics, Vol. 66, pp. 32-46.

Sjöholm F. (1999), Exports, imports and productivity: results from Indonesian Establishment data, World Development, Vol. 27, no. 4, pp. 705-717.

State Service for Intellectual Property of Ukraine, www.uipv.org/ua/archive.

State Statistics Service of Ukraine, www.ukrstat.gov.ua.

Van Long N., Raff H., Stähler F. (2011), Innovation and trade with heterogeneous firms, Journal of International Economics, Vol. 84, no. 2, pp. 149-159.

Zhang Y.A., Li Y., Li H. (2014), FDI spillovers over time in an emerging market: The roles of entry tenure and barriers to imitation, Academy of Management Journal, Vol. 57, no 3, pp. 698-722. 